\title{
Survival of atraumatic restorative treatment (ART) sealants and restorations: a meta-analysis
}

\author{
Rodrigo G. de Amorim • Soraya C. Leal • \\ Jo E. Frencken
}

Received: 15 July 2010 /Accepted: 10 January 2011 /Published online: 28 January 2011

(C) The Author(s) 2011. This article is published with open access at Springerlink.com

\begin{abstract}
The purpose of this study is to perform a systematic investigation plus meta-analysis into survival of atraumatic restorative treatment (ART) sealants and restorations using high-viscosity glass ionomers and to compare the results with those from the 2005 ART metaanalysis. Until February 2010, four databases were searched. Two hundred four publications were found, and 66 reported on ART restorations or sealant survival. Based on five exclusion criteria, two independent reviewers selected the 29 publications that accounted for the meta-analysis. Confidence intervals (CI) and or standard errors were calculated and the heterogeneity variance of the survival rates was estimated. Location (school/clinic) was an independent variable. The survival rates of single-surface and multiple-surface ART restorations in primary teeth over the first 2 years were $93 \%$ (CI, 91-94\%) and 62\% (CI, 51-73\%), respectively; for single-surface ART restorations in permanent teeth over the first 3 and 5 years it was $85 \%(\mathrm{CI}, 77-91 \%)$ and $80 \%$ (CI, 76-83\%), respectively and for multiple-surface ART restorations in permanent teeth over 1 year it was
\end{abstract}

R. G. de Amorim

Department of Dentistry, Faculty of Health Science,

University of Brasilia,

Brasília, Federal District, Brazil

S. C. Leal

Department of Dentistry, Faculty of Health Science,

University of Brasilia,

Brasília, Federal District, Brazil

\section{J. E. Frencken $(\bowtie)$}

Department of Global Oral Health, College of Dental Sciences,

Radboud University Nijmegen Medical Centre,

P.O. Box 9101, 6500, HB Nijmegen, The Netherlands

e-mail: j.frencken@dent.umcn.nl
86\% (CI, 59-98\%). The mean annual dentine lesion incidence rate, in pits and fissures previously sealed using ART, over the first 3 years was $1 \%$. No location effect and no differences between the 2005 and 2010 survival rates of ART restorations and sealants were observed. The short-term survival rates of single-surface ART restorations in primary and permanent teeth, and the caries-preventive effect of ART sealants were high. Clinical relevance: ART can safely be used in singlesurface cavities in both primary and permanent teeth. ART sealants have a high caries preventive effect.

Keywords Atraumatic restorative treatment - Glassionomer · Survival $\cdot$ Restorations $\cdot$ Sealants $\cdot$ Meta-analysis

\section{Introduction}

The first meta-analysis on the quality of atraumatic restorative treatment (ART) sealants and ART restorations was carried out 5 years ago [1]. The results showed high percentages of ART restorations in single-surface cavities in both primary and permanent teeth; unsatisfactory percentages regarding survival of ART restorations in multiplesurface cavities in primary teeth; high percentages of dentine carious lesion-free pits and fissures related to ART sealants and significantly higher survival percentages in ART restorations in which high-viscosity glass ionomers had been used than in those in which medium viscosity ones had been used.

The number of studies investigating the various aspects of the ART approach has increased over the last 5 years. Many of these have focused on the survival of ART restorations. As the ART approach is being utilised by an ever-increasing number of dental professionals around the 
world, there is a need to update the data about the longevity of ART sealants and ART restorations. The present publication reports the findings of a systematic review with meta-analysis on the survival of ART restorations in primary and permanent teeth and on the retention and caries-preventive effect of high-viscosity glass-ionomer ART sealants applied in permanent teeth.

\section{Materials and methods}

Data collection The literature search of publications indexed in the English language was carried out in PubMed and Medline. For the Portuguese and Spanish languages, the search covered the LILACS and BBO databases. All publications listed until 1 February 2010 were analysed. The English keywords used were: "dental", "survival", "Atraumatic Restorative Treatment (ART)", "ART technique", "ART restorations", "ART sealants". The Portuguese search terms were: "Tratamento Restaurador Atraumático", "cimentos de ionômero de vidro" AND "restauração dentária permanente", "cimentos de ionômero de vidro" AND "selantes de fossas e fissuras". The Spanish keyword was "Tratamiento Restaurador Atraumático".

A total of 184 (PubMed), 144 (Medline), 45 (LILACS) and 57 (BBO) publications related to ART were found. All publications found in Medline were also included in PubMed. Concerning Portuguese/Spanish references, 13 publications listed in LILACS did not appear in BBO, while 25 publications listed in BBO were not included in LILACS. Publications whose titles or abstracts did not report on the survival results of ART restorations or ART sealants were immediately excluded. Four publications in English were found in the list of references of extracted publications [2-5] and one submitted manuscript became known to the authors (personal communication), increasing the total number of publications eligible for the metaanalysis to 66 (54 in English and 12 in Portuguese/ Spanish). The sequence followed, from retrieving a publication to its inclusion in the meta-analysis, is shown in Figs. 1 and 2.

The exclusion criteria for the meta-analysis were formulated as follows: (1) survival results $<1$ year; (2) incorrect statistical survival analysis; (3) ART performed by a non-graduated dentist; (4) low- or medium-viscosity glass ionomer or other material used with ART restoration or sealant; (5) cavity restoration with rotary instruments was termed 'ART'. In cases where the content of a publication was unclear, authors were contacted by e-mail. If no response was received within a month, the publication was excluded. Table 1 shows the reason(s) for excluding 37 publications. Finally, the database used for the meta- analysis comprised 29 publications reporting on 27 studies from 18 countries.

Investigator agreement Two investigators independently extracted the survival percentages, corresponding standard errors or confidence intervals (CI) and number of sealants/ restorations for the included studies from the documents published up to June 2005 [1]. RGA and JF independently extracted the requested information from the studies published in English between 1 June 2005 and 1 February 2010. RGA and SL independently extracted the requested information from the studies published in Portuguese and Spanish. A few differences existed between the investigators about articles extracted but all disagreements were resolved through discussion and consensus.

Quality of the included publications The quality assessment of the included studies was based on the following: (a) information provided about the sample recruitment; (b) the baseline DMFT/S and/or dmft/s scores provided; (c) whether a prevention programme was reported in combination with the ART approach; (d) whether the operators were trained in ART; (e) whether the evaluators were calibrated and (f) whether the evaluators were independent.

Homogeneity of survival results Homogeneity of survival results of high-viscosity glass-ionomer ART restorations in primary teeth was obtained for single surfaces at year 2 only. Homogeneity of survival results of single-surface high-viscosity glass-ionomer ART restorations in permanent teeth was obtained for years 5 and 6 . Homogeneity of the survival results of partly and fully retained highviscosity glass ionomer ART sealants, and dentine lesionfree sealed pits and fissures in relation to high-viscosity glass ionomer ART sealants, was obtained for years 2 and 3 , and for years $1-6$, respectively. Testing for homogeneity resulted in a need to correct the variance of the individual survival percentages of ART restorations and ART sealants for the years that showed heterogenous results.

Statistical analysis The analyses were done by a statistician. In cases where only survival percentages and number of sealants/restorations had been presented in publications, the $95 \%$ CI was obtained from statistical tables. CIs were used in calculating the standard error for the survival percentages, according to the following equation: $\mathrm{SE}=($ upper - lower $) / 4$. Survival percentages per year within selected groups were combined by weighting with the reciprocal standard error variances and tested for homogeneity. If homogeneity was rejected at a level of 0.05 , statistical software $R$, version 2.10.1 was used for estimating the heterogeneity variance and adding it to the pooled variance [6]. The independent variable, location, 
Fig. 1 Flow chart of retrieved English publications from keywords to included publications reporting survival results of ART sealants or ART restorations
Pubmed Medline

$184 \quad 144$ 184

49

54
Total number of publications retrieved on key words

Excluded publications for the following reasons:

- non-survival ART related publications $(n=64)$

- ART mentioned in general dentistry publications $(n=39)$

- ART mentioned in non-dental publications $(n=8)$

- ART related letters $(n=8)$

- ART mentioned in non-traceable journals (Chinese) $(n=5)$

- Survival results repeated in other journal/language $(n=5)$

- Survival using resin composite $(n=2)$

- Survival on root surfaces $(n=2)$

- Survival on anterior teeth $(n=2)$

Number of eligible publications minus excluded publications not reporting survival of ART sealants or ART restorations

Added publications:

- retrieved in list of references $(n=4)$

- personal communication $(n=1)$

Number of publications before application of exclusion criteria

Excluded publications $(\mathrm{n}=25)$ (Table 1$)$

Included publications for the meta-analysis was defined as 'dental clinic or primary school'. Differences between groups were tested, using the $t$ test. Statistically significant difference was set at $\alpha=0.05$.

\section{Results}

ART restorations The survival percentages, standard errors and $95 \%$ CI of single- and multiple-surface ART restorations in primary teeth are presented in Tables 2 and 3, respectively. The mean annual failure rates of single-surface and multiplesurface ART restorations in primary teeth over the first 2 years were $3.5 \%$ and $19 \%$, respectively. The survival percentages, standard errors and 95\% CI of single-surface and multiple-surface ART restorations in permanent teeth are presented in Tables 4 and 5. The mean annual failure rates of single-surface ART restorations using high-viscosity glass ionomers in permanent teeth over the first 3 and 5 years were $5.0 \%$ and $4.0 \%$, respectively. The mean annual failure rate of multiple-surface ART restorations using high-viscosity glass ionomers in permanent teeth was $14 \%$ over the first year. No location effect was observed $(p>0.05)$.

ART sealants The survival percentages, standard errors and 95\% CI of fully and partially retained ART sealants in permanent teeth are presented in Table 6. The mean annual failure rate of completely lost high-viscosity glass ionomers 
Fig. 2 Flow chart of retrieved Portuguese/Spanish publications from keywords to included publications reporting survival results of ART sealants or ART restorations

\section{LILACS $\quad$ BBO 45 70 57}

Total number of publications retrieved on key words

Excluded publications for the following reasons:

- non-survival ART related publications $(n=54)$

- ART mentioned in non-traceable thesis $(n=4)$

12

Number of publications before application of exclusion criteria

Excluded publications ( $n=12)$ (Table 1)

Number of eligible publications minus excluded publications not reporting survival of ART sealants or ART restorations

Included publications for the meta-analysis sealants in permanent teeth over the first 3 years was $9.3 \%$. The survival percentages and $95 \% \mathrm{CI}$ of caries-free pits and fissures in permanent teeth previously sealed using the press-finger technique (ART) for high-viscosity glass ionomers are presented in Table 7. The mean annual caries incidence rate over the first 3 years, in pits and fissures previously sealed using the press-finger technique, was $1.0 \%$. No location effect was observed $(p>0.05)$.

Survival results of ART restorations in 2005 and 2010 The survival results and $95 \%$ CI of ART restorations using high-viscosity glass ionomers in posterior teeth by type of restoration, year of survival and year of meta-analysis are presented in Table 8. No statistically significant differences in survival percentages of ART restorations were observed between the meta-analyses carried out in 2005 and $2010(p>0.05)$.

Quality assessment None of the included publications contained information about all of the six criteria chosen for quality assessment.

\section{Discussion}

The present meta-analysis on ART restoration and ART sealant survival differs from the one carried out in 2005, as it included Portuguese and Spanish databases in its systematic literature review. Since ART has increasingly been used in many Latin American and Caribbean countries [4], the search was extended to libraries containing publications in these two languages. However, none of the 12 eligible publications in Portuguese/Spanish met the inclusion criteria.

The strength of the systematic review, which is at the heart of meta-analysis, is the assessment of all relevant studies of adequate quality, whether published or unpublished [7]. In the present investigation, only one unpublished manuscript reporting on survival rates of ART sealants over 6 years was included in the database. Fortunately, the 3-year results of the same study had been published [8], so aspects of the quality of the unpublished manuscript could be checked.

The decision to include only studies that had used highviscosity glass-ionomers was based on the results of the first meta-analysis covering ART restorations and ART sealants [1]. Since 1995, it has become common practice to consider high-viscosity glass ionomers as the correct glass ionomer for use in producing ART restorations and ART sealants [9]. Although it is easy to understand that a glass ionomer with improved physical characteristics (specially the fracture toughness) will lead to higher survival rates of restorations, many dental practitioners have different thoughts regarding its use for sealing pits and fissures. They hold the opinion that low- or medium-viscosity glass ionomers, being less viscous than high-viscosity glass 
Table 1 Listing and reasons for exclusion of publications that have reported about survival of ART restorations and ART sealants

\begin{tabular}{|c|c|c|c|c|c|c|}
\hline First author & Language & $\begin{array}{l}\text { Survival } \\
<1 \text { year }\end{array}$ & $\begin{array}{l}\text { Operator not a } \\
\text { dentist/dental } \\
\text { therapist }\end{array}$ & $\begin{array}{l}\text { Incorrect statistical } \\
\text { survival analysis }\end{array}$ & $\begin{array}{l}\text { Low- and medium- } \\
\text { viscosity GIC or } \\
\text { other materials }\end{array}$ & $\begin{array}{l}\text { ART with } \\
\text { rotary } \\
\text { instrument }\end{array}$ \\
\hline Oba et al. [38] & English & & & $\mathrm{x}$ & & \\
\hline Faccin et al. [39] & English & & $\mathrm{x}$ & & $\mathrm{x}(\operatorname{Resin})$ & \\
\hline Roeleveld et al. [40] & English & & $\mathrm{x}$ & & & \\
\hline Kemoli et al. [16] & English & & $\mathrm{x}$ & $\mathrm{x}$ & & \\
\hline Barata et al. [41] & English & & & $\begin{array}{l}\text { Mixture of class I, } \\
\text { II, III and IV }\end{array}$ & & \\
\hline Dülgergil et al. [42] & English & $\mathrm{x}$ & & & & \\
\hline Lopez et al. [43] & English & & $\mathrm{x}$ & & & \\
\hline Cefaly et al. [44] & English & $\mathrm{x}$ & & & & \\
\hline Bresciani et al. [45] & English & $\mathrm{x}$ & & & & \\
\hline Mallow et al. [46] & English & & $\mathrm{x}$ & & $\mathrm{x}$ & \\
\hline Abid et al. [47] & English & & & $\mathrm{x}$ & & \\
\hline Motsei et al. [48] & English & & & $\mathrm{x}$ & & \\
\hline $\begin{array}{l}\text { Smith et al. [2] and } \\
\text { Kalf-Scholte et al. [49] }\end{array}$ & English & & & & $\mathrm{x}$ & \\
\hline Phantumvanit et al. [50] & English & & & & $\mathrm{x}$ & \\
\hline Mandari et al. [51, 52] & English & & & & $\mathrm{x}$ & \\
\hline Frencken et al. [53] & English & & & & $\mathrm{x}$ & \\
\hline De Souza et al. [54] & English & $\mathrm{x}$ & & & & \\
\hline Frencken et al. [55] & English & & & & $\mathrm{x}$ & \\
\hline Wang et al. [56] & English & & $\mathrm{x}$ & & & \\
\hline Lo and Holmgren [57] & English & & $\mathrm{x}$ & & & \\
\hline Yee [58] & English & & $\mathrm{x}$ & & & \\
\hline Van den Dungen et al.[59] & English & & $\mathrm{x}$ & & & \\
\hline Zanata et al. [60] & English & & & & & $\mathrm{x}$ \\
\hline Falbo et al. [61] & Spanish & & & $\mathrm{x}$ & & \\
\hline Moraes et al. [62] & Portuguese & & & $\mathrm{x}$ & & \\
\hline Oliveira et al. [63] & Portuguese & $\mathrm{x}$ & & & & \\
\hline Silva et al. [64] & Portuguese & $\mathrm{x}$ & & & & \\
\hline Bresciani et al. [65] & Portuguese & $\mathrm{x}$ & & & & \\
\hline Peres et al. [66] & Portuguese & $\mathrm{x}$ & & & & \\
\hline Coelho et al. [67] & Portuguese & & & & $\mathrm{x}$ & \\
\hline Ewoldsen et al. [68] & Spanish & & & & $\mathrm{x}$ & \\
\hline Oliveira [69] & Portuguese & & & & $\mathrm{x}$ & \\
\hline Bustamante et al. [70] & Spanish & & & $\mathrm{x}$ & & \\
\hline Edelberg \& Basso [71] & Spanish & & & $\mathrm{x}$ & & \\
\hline Figueiredo et al. [72] & Portuguese & & & $\mathrm{x}$ & & \\
\hline
\end{tabular}

ionomers, would flow more easily into the deepest parts of pits and fissures, which is in line with the practice of placing resin composite sealants. However, the fissure penetration depth of high-viscosity glass ionomers sealants placed in accordance with the "finger pressure" technique [10] does not differ from that of resin composite sealants [11]. Furthermore, the survival rates of retained highviscosity glass-ionomer ART sealants were found to be higher than those of medium-viscosity glass ionomers [1,
12]. There is, therefore, sufficient evidence that using highviscosity glass ionomers for placing ART sealants is the better option.

Studies that used rotary instruments to remove carious tissues or to gain access to the dentine lesion were also excluded. As one of the main fundamentals of the ART approach is the use of hand instruments only, preparing cavities with rotary instrumentation and describing the process as ART, is a misuse of the ART approach [13]. If 
Table 2 Overview of survival results (in percent) SE and 95\% CI of single-surface ART restorations using high-viscosity glass ionomers in primary posterior teeth by location and year of survival

\begin{tabular}{|c|c|c|c|c|c|c|c|c|c|c|}
\hline \multirow[t]{3}{*}{ Authors } & \multirow[t]{3}{*}{ Location } & \multicolumn{9}{|c|}{ Year of survival } \\
\hline & & \multicolumn{3}{|l|}{1} & \multicolumn{3}{|l|}{2} & \multicolumn{3}{|l|}{3} \\
\hline & & Survival & SE & $\mathrm{CI}$ & Survival & SE & $\mathrm{CI}$ & Survival & $\mathrm{SE}$ & $\mathrm{CI}$ \\
\hline Honkala et al. [73] & Clinic & 99 & 2.0 & & 91 & 4.0 & & & & \\
\hline Taifour et al. [74] & Clinic & 95 & 1.0 & & 91 & 1.3 & & 86 & 1.8 & \\
\hline Yip et al. [75] and Yu et al. [76] & Clinic & 95 & 3.8 & & 89 & 6.5 & & & & \\
\hline Yip et al. [75] and Yu et al. [76] & Clinic & 94 & 4.5 & & 94 & 4.5 & & & & \\
\hline Louw et al. [77] & School & 96 & 2.3 & & & & & & & \\
\hline Luo et al. [78] and Lo et al. [79] & School & 93 & 3.4 & & 94 & 3.8 & & & & \\
\hline Van Gemert et al. [17] & School & & & & & & & 43 & 10.9 & \\
\hline Ersin et al. [80] & School & 100 & 0.8 & & & & & & & \\
\hline Menezes et al. [34] & Clinic & 82 & 7.3 & & & & & & & \\
\hline Yassen [81] & School & 74 & 7.3 & & & & & & & \\
\hline Weighted mean score & & 95 & & $91-98$ & 93 & & $91-94$ & 66 & & $13-99$ \\
\hline
\end{tabular}

$S E$ standard error

${ }^{\mathrm{a}, \mathrm{b}}$ Same study but different glass ionomer cement

extra retention is required, especially in proximal restorations, retention niches can be made with special hand instruments, as described by Cefaly et al. [14]. Rutar et al. [15] proposed a change in the restorative technique in order to improve survival of multiple-surface glass-ionomer restorations in primary teeth. They suggested lowering the isthmus and keeping it out of occluding contact.
People not yet qualified in medical sciences do not generally conduct studies investigating the quality of a dental treatment approach in vivo or carry out the evaluation of such a treatment [16]. That was the reason for exclusion from this meta-analysis of studies whose restorative procedures had been performed by a dental undergraduate.

Table 3 Overview of survival results (in percent) SE and 95\% CI of multiple-surface ART restorations using high-viscosity glass ionomers in primary posterior teeth by location and year of survival

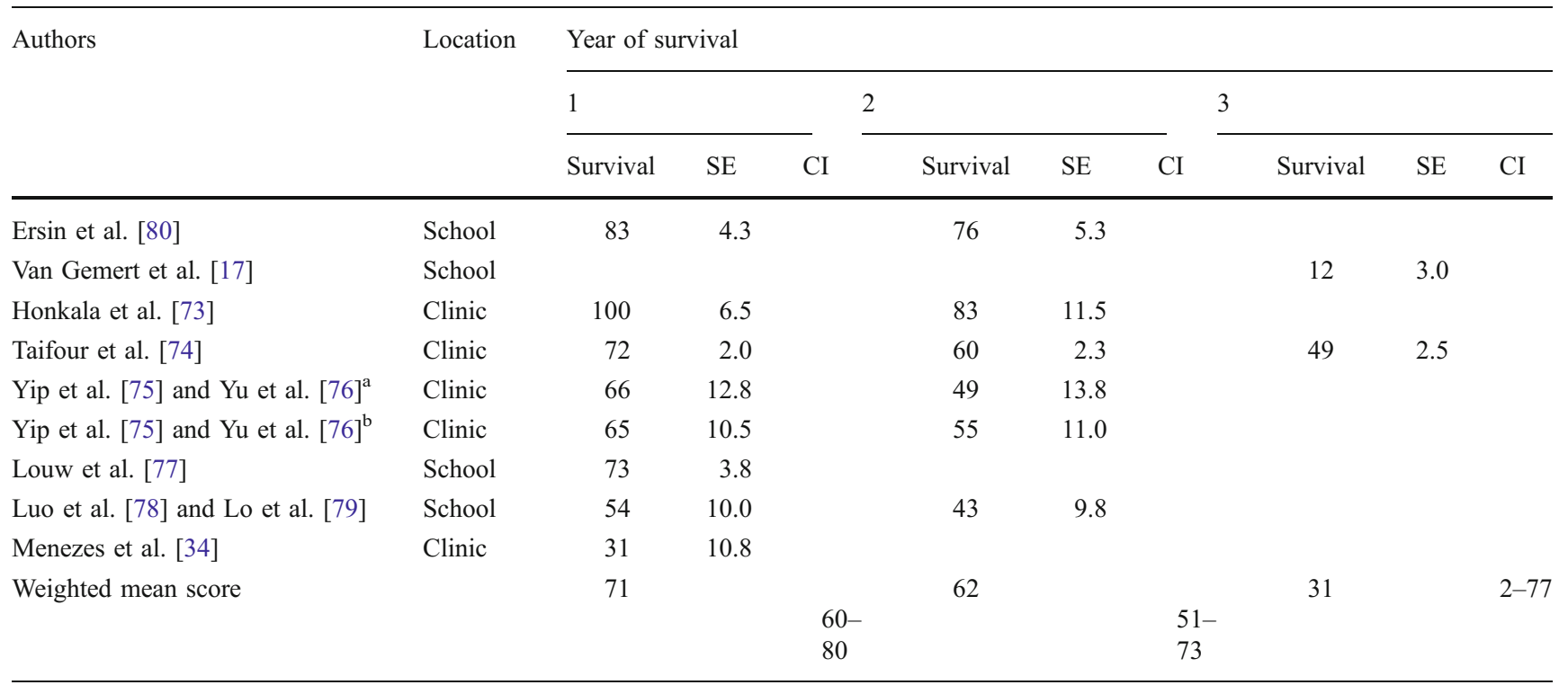

SE standard error

${ }^{\mathrm{a}, \mathrm{b}}$ Same study but different glass ionomer cement 


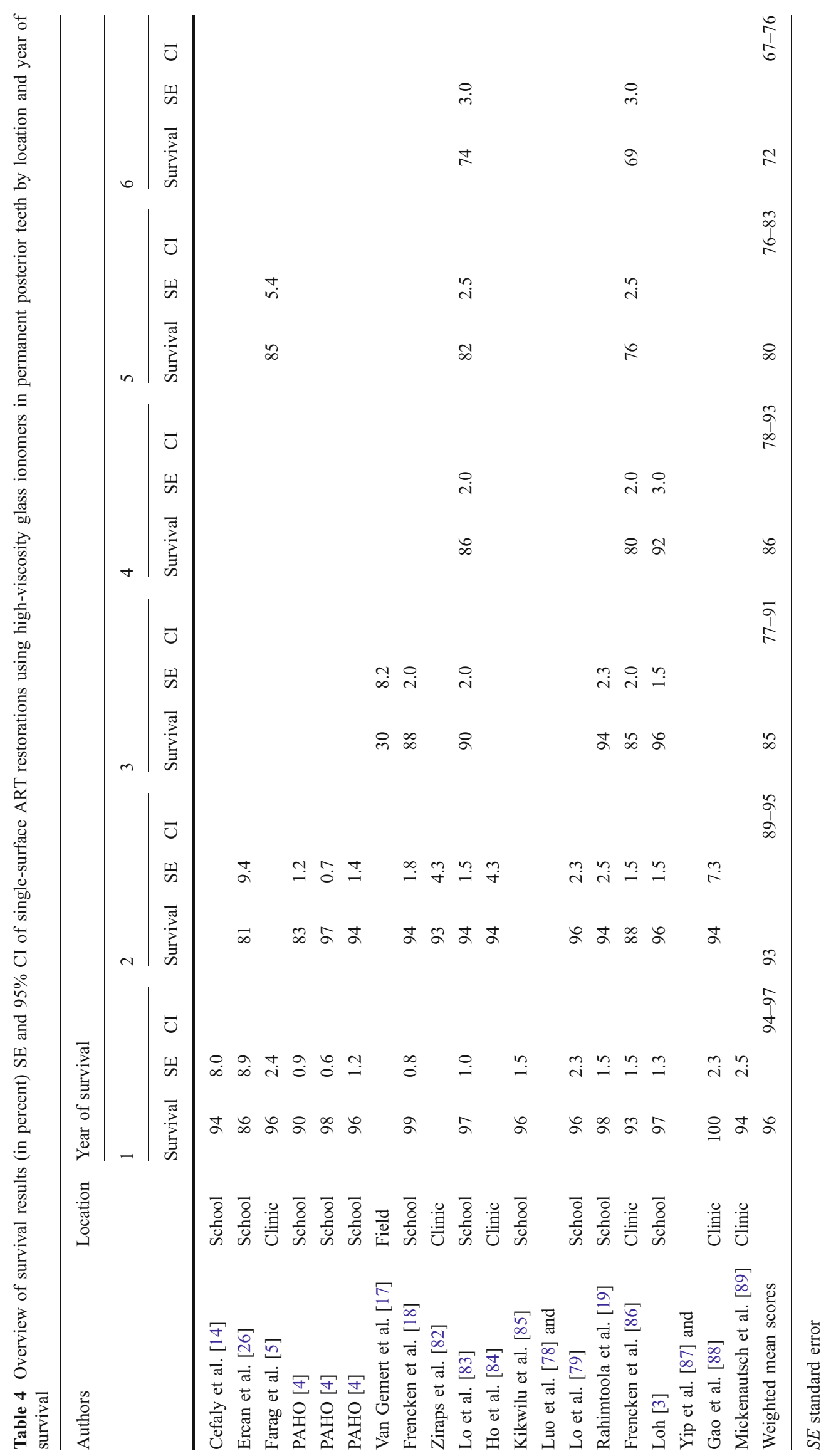




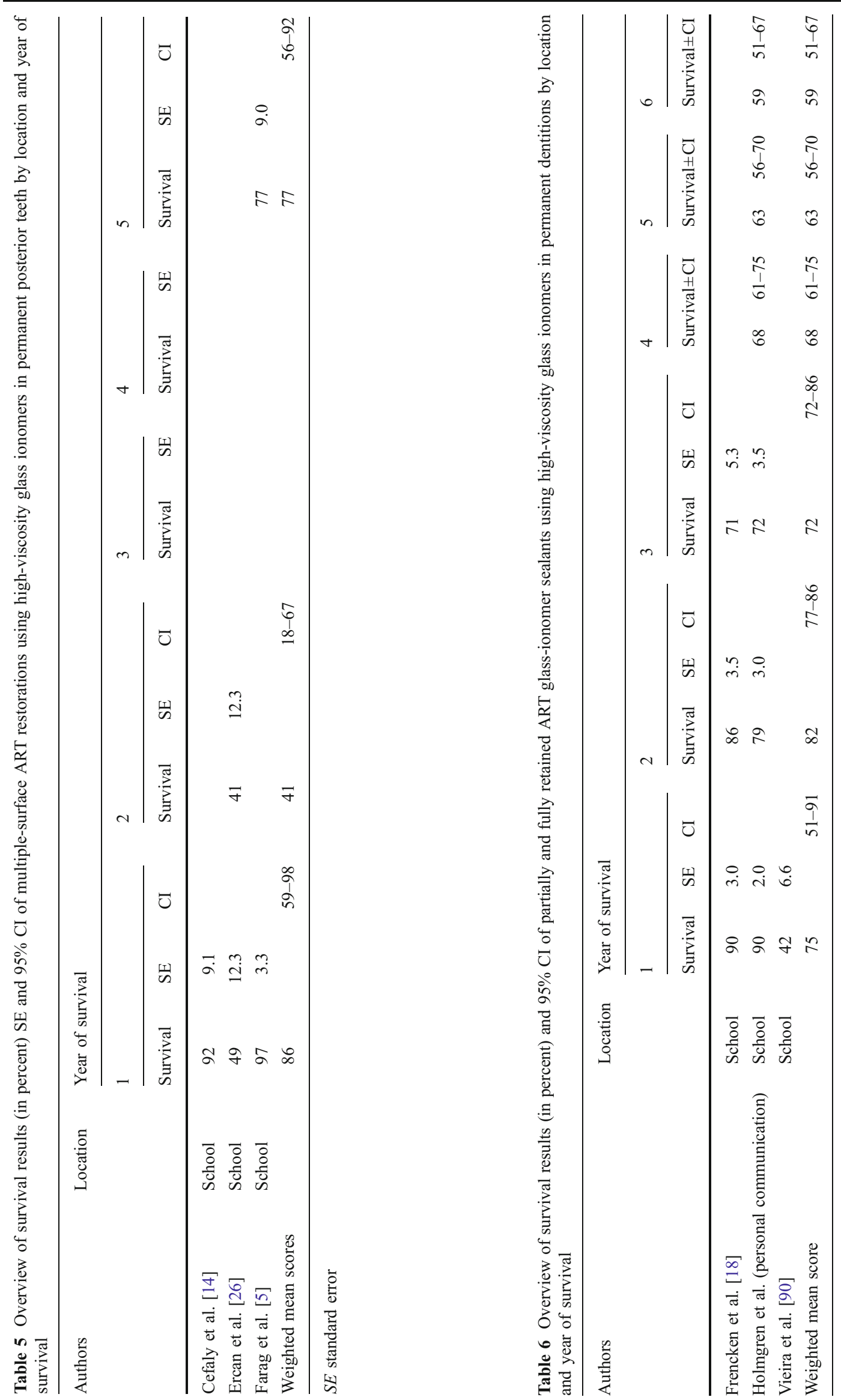




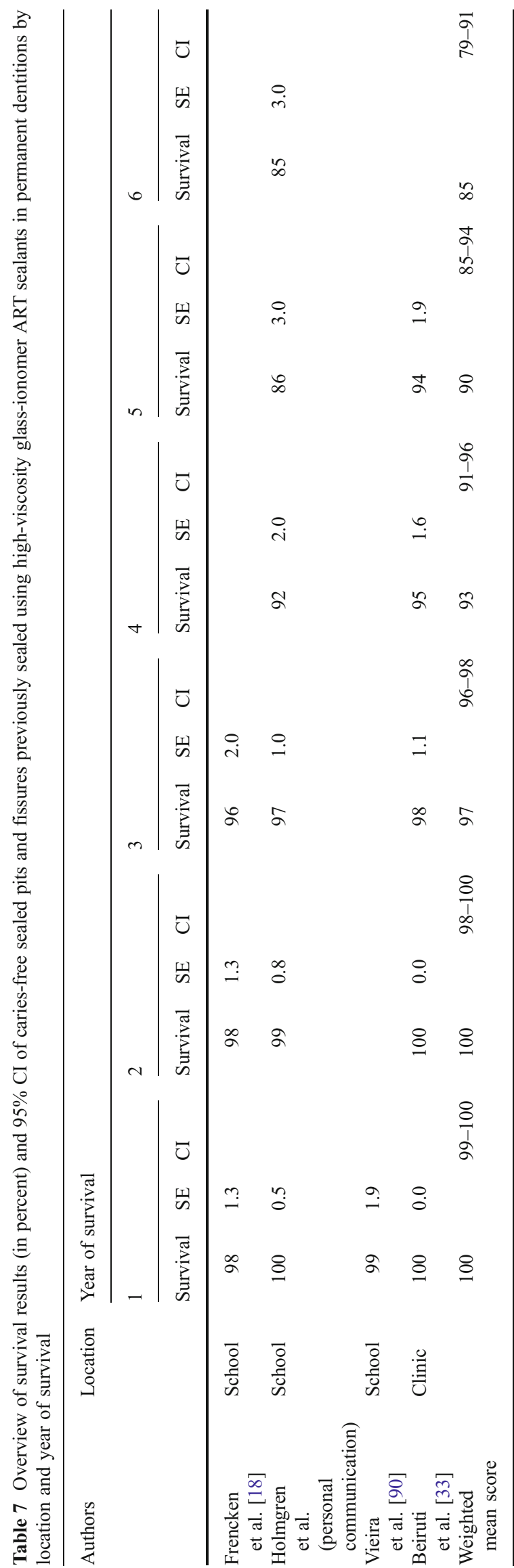

There are certain aspects related to the methodology of a study that can interfere with its quality and, therefore, affect the level of evidence provided by that specific research. The quality assessment of primary studies included in the present meta-analysis was based on the reporting of relevant methodological aspects that should be part of any clinical trial, with the aim of testing the efficacy of an intervention. It is expected that poor oral hygiene along with high scores of $\mathrm{DMFT} / \mathrm{S}$ or $\mathrm{dfmt} / \mathrm{s}$ at baseline may have an overall impact on the survival of restorations in general, and those of ART restorations in particular [17]. For that reason, this information was considered important during analysis of the outcome of the individual studies. In this regard, it was observed that most of the included publications did not report the oral health status of the subjects enrolled in the trial, nor did they state that an oral health programme was implemented alongside the treatment provided. Another important aspect that was taken into account referred to the training of operators. An operator effect on the quality of ART restorations and sealants applied by dental practitioners has been reported [17-19]. However, only a few included studies provided information about whether and how the operators were trained. Finally, whether evaluators had been calibrated and were independent was also assessed. Information about this aspect was not always provided. When it was provided, the wording was not clear enough to enable the reader to understand how the calibration of evaluators was performed. In an attempt to summarise the quality aspect of the included publications it can be said that none provided information on all the quality assessment criteria used. Therefore, in order to improve the quality of clinical trials and the reliability of the survival rates of ART restorations and ART sealants, there is a need for researchers to better design and/or report proposed methodological characteristics in the study protocols.

The number of included long-term studies was low. In some occasions, as for the 3-year survival of ART restorations in single and multiple surfaces, the survival rates amongst the few longer term studies differed significantly and that resulted in large CIs for the weighted mean survival scores. Therefore, one should be careful in drawing conclusions from the mean survival rates per year that is made up of only a few study outcomes.

The present meta-analysis showed short-term high mean survival rates for single-surface ART restorations in both primary and permanent dentitions; short-term medium mean survival rates for multiple-surface ART restorations in primary teeth; inconclusive results for multiple-surface ART restorations in permanent teeth; reasonably high survival rates of partially and fully retained ART sealants and a high short-term dentine lesion-preventive effect for ART sealants, thus confirming the results of the first metaanalysis on ART restorations and ART sealants [1]. 
Table 8 Survival results (in percent) and 95\% CI of ART restorations using high-viscosity glass ionomers in posterior teeth by type of restoration, year of survival and year of meta-analysis

\begin{tabular}{|c|c|c|c|c|c|c|c|}
\hline Type of ART restoration & $\begin{array}{l}\text { Survival } \\
\text { years }\end{array}$ & $\begin{array}{l}N \text { pubs in meta-analysis, } \\
\text { June } 2005\end{array}$ & Survival & $95 \% \mathrm{CI}$ & $\begin{array}{l}N \text { pubs in meta-analysis, } \\
\text { February } 2010\end{array}$ & Survival & $95 \% \mathrm{CI}$ \\
\hline \multirow[t]{3}{*}{ Single surface in primary teeth } & 1 & 7 & 95 & $94-97$ & 9 & 95 & $91-98$ \\
\hline & 2 & 7 & 91 & $88-93$ & 6 & 93 & $91-94$ \\
\hline & 3 & 1 & 86 & $83-90$ & 2 & 66 & $13-99$ \\
\hline \multirow{3}{*}{$\begin{array}{l}\text { Multiple surfaces in primary } \\
\text { teeth }\end{array}$} & 1 & 7 & 73 & $70-77$ & 8 & 71 & $60-80$ \\
\hline & 2 & 6 & 59 & $55-64$ & 6 & 62 & $51-73$ \\
\hline & 3 & 1 & 49 & $44-54$ & 2 & 31 & $2-77$ \\
\hline \multirow{6}{*}{$\begin{array}{l}\text { Single surface in permanent } \\
\text { teeth }\end{array}$} & 1 & 10 & 97 & $97-98$ & 15 & 96 & $94-97$ \\
\hline & 2 & 10 & 94 & $92-95$ & 13 & 93 & $89-95$ \\
\hline & 3 & 5 & 92 & $90-93$ & 6 & 85 & $77-91$ \\
\hline & 4 & 3 & 85 & $82-87$ & 3 & 86 & $78-93$ \\
\hline & 5 & 2 & 79 & $76-83$ & 3 & 80 & $76-83$ \\
\hline & 6 & 2 & 72 & $67-76$ & 2 & 72 & $67-76$ \\
\hline \multirow{5}{*}{$\begin{array}{l}\text { Multiple surfaces in permanent } \\
\text { teeth }\end{array}$} & 1 & 0 & & & 3 & 86 & 59-98 \\
\hline & 2 & 0 & & & 1 & 41 & $18-67$ \\
\hline & 3 & 0 & & & 0 & & \\
\hline & 4 & 0 & & & 0 & & \\
\hline & 5 & 0 & & & 1 & 77 & 56-92 \\
\hline
\end{tabular}

N pubs number of publications

In contrast to expectations, the survival results of ART restorations in all types of cavities in both types of dentitions did not show a location effect. This implies that ART restorations placed in the well-equipped dental clinic did not survive longer than those placed in primary schools under conditions more difficult for the administration of treatment.

It had been suggested that resin-modified glass ionomer should be used to improve the survival of multiple-surface restorations in primary teeth [20-22]. This suggestion is supported by a critical review which concluded that the longevity of resin-modified glass-ionomer restorations in primary teeth was similar to that of amalgam, whereas the lifespan of conventional, low- to medium-viscosity glass ionomer was shown to be significantly shorter [23]. The ART approach allows the use of all adhesive materials, including resin-modified glass ionomers and resin composites [13]. Self-etch resin composite has been used with ART in attempts to increase the survival rate of multiplesurface ART restorations in primary teeth [24, 25]. Unfortunately, the survival results were low. They were also lower than those reported for high-viscosity glassionomers in the 2005 meta-analysis on ART [1]. This was largely due to the poor quality of the self-etch bonding system used. As reported recently, the use of resin-modified glass ionomers with ART should be investigated [26].

The number of studies reporting on the retention and dentine lesion-preventing effect of ART sealants had hardly increased over the 4.7-year period following the 2005 systematic review and meta-analysis on ART [1]. As the number of studies assessing ART sealants was low and the dentine lesion-preventive effect of ART sealants was high in 2005, the expectation was that more clinical trials would have been conducted since then. Probably few studies were done because many professionals are used to strictly correlating the caries-preventive effect of a sealant with its complete clinical retention. Many studies have shown resinbased sealant to have a high level of retention [27]; higher than those of low- and medium-viscosity glass ionomers [10, 28]. However, the retention over time of high-viscosity glass ionomers used in placing ART sealants was higher than that of the low- to medium-viscosity glass ionomers [1].

A possible reason for the high dentine lesion-preventive effect of high-viscosity glass-ionomer ART sealants in their clinically apparent absence has recently been reported [29]. SEM images of pits and fissures apparently free of highviscosity glass-ionomer sealant material revealed remnants of glass ionomer-like material left in the deepest parts of pits and fissures. These remnants, most probably present because of the cohesive failure of glass-ionomers [30], may continue to constitute a physical barrier against the acid produced in the plaque. This finding may also explain the results of a systematic review [31] and a meta-analysis [32], which found no evidence that either material was superior to the other in the prevention of dental caries. In the present metaanalysis, although the survival rate of ART sealants after 3 years was $72 \%$, the result for dentine lesion-free sealed pits 
and fissures was $97 \%$ after the same period. This finding is in agreement with that of Beiruti et al. [33]. They showed that high-viscosity glass ionomer ART sealants had a four times higher chance than resin-based sealants, of preventing caries development in re-exposed pits and fissures of occlusal surfaces of first molars over a 1- to 3-year period.

Most of the included studies had used the (modified) ART criteria for evaluating the survival of sealants and restorations or the United States Public Health Services (USPHS) criteria to assess restoration survival. According to Holmgren et al. [8], no significant differences between the two sets of criteria were detected regarding survival outcomes of ART restorations. As the USPHS criteria have usually been applied in assessing the survival of other restorative materials, it is reasonable to assume that the outcomes of this meta-analysis are comparable to those from non-ART studies. Only one study applied criteria different from ART and USPHS [34].

The USPHS criteria have been criticized for their limited sensitivity in detecting improved clinical performances of restorative materials currently in use. Consequently, the FDI criteria, a new discriminative set of criteria, were developed [35]. The FDI criteria, as well as the common ART criteria, were used to assess ART restorations [36]. No significant differences in survival estimates were found between the two sets of criteria. However, more ART restorations failed according to the ART criteria than according to the FDI criteria, which is congruent with reported results regarding the differences between the ART and USPHS criteria. There is a need, therefore, to reassess the ART criteria [36, 37].

In conclusion, the systematic review with meta-analysis showed high survival rates for single-surface ART restorations using high-viscosity glass ionomers in primary and permanent teeth over 2 and 5 years, respectively. The shortterm survival rates of multiple-surface ART restorations using high-viscosity glass ionomers were low for the primary teeth at 2 years and the number of such studies for the permanent teeth was low. The survival rates and dentine lesion-preventive effect in particular, of highviscosity glass-ionomer ART sealants at 3 years were high, indicating that these are effective alternatives to the traditionally used resin-based sealants. The presented survival rates for ART sealants and ART restorations corroborate the outcomes of the 2005 first meta-analysis on ART and confirm that the ART approach is an effective evidence-based option for managing dental caries.

Acknowledgements We would like to acknowledge the authors of the studies that have made up the database for this meta-analysis. We are very grateful to Dr. E. Bronkhorst for skilful analyses of the data.

Conflict of interest The authors declare that they have no conflict of interest.
Open Access This article is distributed under the terms of the Creative Commons Attribution Noncommercial License which permits any noncommercial use, distribution, and reproduction in any medium, provided the original author(s) and source are credited.

\section{References}

1. Van't Hof MA, Frencken JE, Van Palenstein Helderman WH (2006) The atraumatic restorative treatment (ART) approach for managing dental caries: a meta-analysis. Int Dent J 56:345-351

2. Smith AJE, Chimimba PD, Kalf-Scholte S, Bouma J (1990) Clinical pilot study on new dental filling materials and preparation procedures in developing countries. Community Dent Oral Epidemiol 18:309-312

3. Loh KH (2003) An ART technique in the mobile dental squad in Malaysia: a four-year review. Malaysian Dent J 24:95-101

4. Pan American Health Organization (2006) Oral health of low income children. Procedures for atraumatic restorative treatment. Final report. PAHO, Washington

5. Farag A, van der Sanden WJM, Abdelwahab H, Mulder J, Frencken JE (2009) 5-Year survival of ART restorations with and without cavity disinfection. J Dent 37:468-474

6. R Development Core Team (2009) R: A language and environment for statistical computing. R Foundation for Statistical Computing, Vienna, Austria. ISBN 3-900051-07-0, URL http://www.R-project.org Accessed 4 April 2010

7. Mulrow CD (1994) Rational for systematic reviews. Br Med J 309:597-599

8. Holmgren CJ, Lo ECM, Hu DY, Wan HC (2000) ART restorations and sealants placed in Chinese school children - results after 3 years. Community Dent Oral Epidemiol 28:314-320

9. Frencken JE (2010) The ART approach using glass-ionomers in relation to global oral health care. Dent Mat 26:1-6

10. Mejàre I, Mjör IA (1990) Glass ionomer and resin-based fissure sealants: a clinical study. Scand J Dent Res 98:345-350

11. Smales RJ, Gao W, Ho FT (1997) In vitro evaluation of sealing pits and fissures with newer glass-ionomer cements developed for the ART technique. J Clin Pediatr Dent 21:321-323

12. Weerheijm KL, Kreulen CM, Gruythuisen RJ (1996) Comparison of retentative qualities of two glass-ionomer cements used as fissure sealants. ASDC J Dent Child 63:265-267

13. Frencken JE, Leal SC (2010) The correct use of the ART approach. J Appl Oral Sci 18:1-4

14. Cefaly DFG, Bresciani E, Lauris JRP, Barata TJE, Fagundes TC, Navarro MFL (2007) Clinical evaluation of multiple-surface ART restorations: 12 month follow-up. ASDC J Dent Child 74:203-208

15. Rutar J, McAllan L, Tyas MJ (2002) Three-year clinical performance of glass ionomer cement in primary molars. Int $\mathrm{J}$ Paediat Dent 12:146-147

16. Kemoli AM, van Amerongen WE, Opinya G (2009) Influence of the experience of operator and assistant on the survival rate of proximal ART restorations: two-year results. Eur Arch Paediatr Dent 10:227-232

17. Van Gemert-Schriks MC, van Amerongen WE, ten Cate JM, Aartman IH (2007) Three-year survival of single- and two-surface ART restorations in a high-caries child population. Clin Oral Invest 11:337-343

18. Frencken JE, Makoni F, Sithole WD (1998) ART restorations and glass ionomer sealants in Zimbabwe: survival after 3 years. Community Dent Oral Epidemiol 26:372-381

19. Rahimtoola S, Van Amerongen WE (2002) Comparison of two tooth saving preparation techniques for one surface cavities. ASDC J Dent Child 69:16-26 
20. Qvist V, Manscher E, Teglers PT (2004) Resin-modified and conventional glass ionomer restorations in primary teeth: 8-years results. J Dent 32:285-294

21. Qvist V, Laurberg L, Poulsen A, Teglers PT (2004) Class II restorations in primary teeth: 7-year study on three resinmodified glass ionomer cements and a compomer. Eur J Oral Sci 112:188-196

22. Palma-Dibb RG, de Castro CG, Ramos RP, Chimello DT, Chinelatti MA (2003) Bond strength of glass-ionomer cements to caries-affected dentin. J Adhes Dent 5:57-62

23. Qvist V, Poulsen A, Teglers PT, Mjör IA (2010) The longevity of different restorations in primary teeth. Int J Paediatr Dent 20:1-7

24. Eden E, Topaloglu-Ak A, Frencken JE, van'T Hof MA (2006) Survival of self-etch adhesive Class II composite restorations using ART and conventional cavity preparations in deciduous teeth. Am J Dent 19:359-363

25. Topaloglu-Ak A, Eden E, Frencken JE, Oncag O (2009) Two years survival rate of Class II composite resin restorations prepared by ART with and without a chemomechanical caries removal gel in primary molars. Clin Oral Invest 13:325-332

26. Ercan E, Dulgergil T, Soyman M, Dalli M, Yildirim I (2009) A fieldtrial of two restorative materials used with atraumatic restorative treatment in rural Turkey: 24-month results. J Appl Oral Sci 17:307314

27. Muller-Bolla M, Lupi-Pe'gurier L, Tardieu C, Velly AM, Antomarchi C (2006) Retention of resin-based pit and fissure sealants: a systematic review. Community Dent Oral Epidemiol 34:321-336

28. Williams B, Laxton L, Holt RD, Winter GB (1996) Fissure sealants: a 4-year clinical trial comparing an experimental glass polyalkenoate cement with a bis glycidyl methacrylate resin used as fissure sealants. Br Dent J 180:104-108

29. Frencken JE, Wolke J (2010) Clinical and SEM assessment of ART high-viscosity glass-ionomer sealants after 8-13 years in 4 teeth. J Dent 38:59-64

30. Papacchini F, Goracci C, Sadek FT, Monticelli F, Garcia-Godoy F, Ferrari M (2005) Microtensile bond strength to ground enamel by glass-ionomers, resin-modified glass-ionomers, and resin composites used as pit and fissure sealants. J Dent 33:459-467

31. Beiruti N, Frencken JE, Van'T Hof MA, van Palenstein Helderman WH (2006) Caries preventive effect of resin-based and glass ionomer sealants over time: a systematic review. Community Dent Oral Epidemiol 34:403-409

32. Yengopal V, Mickenautsch S, Bezerra AC, Leal SC (2009) Cariespreventive effect of glass ionomer and resin-based fissure sealants on permanent teeth: a meta analysis. J Oral Sci 51:373-382

33. Beiruti N, Frencken JE, van't Hof MA, Taifour D, van Palenstein Helderman WH (2006) Caries-preventive effect of a one-time application of composite resin and glass ionomer sealants after 5 years. Caries Res 40:52-59

34. Menezes JPL, Rosenblatt A, Medeiros E (2006) Clinical evaluation of atraumatic restorations in primary molars: a comparison between 2 glass ionomer cements. ASDC J Dent Child 73:91-97

35. Hickel R, Roulet JF, Bayne S, Heintze SD, Mjör IA, Peters M, Rousson V, Randall R, Schmalz G, Tyas M, Vanherle G (2007) Recommendations for conducting controlled clinical studies of dental restorative materials. Clin Oral Invest 11:5-33

36. Farag A, van der Sanden WJM, Abdelwahab H, Frencken JE (2010) Survival of ART restorations, assessed using selected FDI and the modified ART restoration criteria. Clin Oral Invest (in press)

37. Zanata RL, Fagundes TC, Freitas MCCA, Lauris JRP, Navarro MFL (2010) Ten-year survival of ART restorations in permanent posterior teeth. Clin Oral Invest (in press)

38. Oba AA, Dulgergil T, Sonmez IS, Dogan S (2009) Comparison of caries prevention with glass ionomer and composite resin fissure sealants. J Form Med Assoc 108:844-848
39. Faccin ES, Ferreira SH, Kramer PF, Ardenghi TM, Feldens CA (2009) Clinical performance of ART restorations in primary teeth: a survival analysis. J Clin Pediatr Dent 33:295-298

40. Roeleveld AC, van Amerongen WE, Mandari GJ (2006) Influence of residual caries and cervical gaps on the survival rate of class II glass ionomer restorations. Eur Arch Paediatr Dent 7:85-91

41. Barata TJ, Bresciani E, Mattos MC, Lauris JR, Ericson D, Navarro MFL (2008) Comparison of two minimally invasive methods on the longevity of glass ionomer cements restorations: short-term results of a pilot study. J Appl Oral Sci 16:155-160

42. Dulgergil CT, Soyman M, Civelek A (2005) Atraumatic restorative treatment with resin-modified glass ionomer material: short term results of a pilot study. Med Princ Pract 14:277-280

43. Lopez N, Simpser-Rafalin S, Berthold P (2005) Atraumatic restorative treatment for prevention and treatment of caries in a underserved community. Am J Public Health 95:1338-1339

44. Cefaly DFG, Barata TJE, Tapety CMC, Bresciani E, Navarro MFL (2005) Clinical evaluation of multisurface ART restorations. J Appl Oral Sci 13:15-19

45. Bresciani E, Carvalho WL, Pereira LCG, Barata TJE, GarciaGodoy F, Navarro MFL (2005) Six-month evaluation of ART onesurface restorations in a community with high caries experience in Brazil. J Appl Oral Sci 13:180-186

46. Mallow PK, Durward CS, Klaipo M (1998) Restoration of permanent teeth in young rural children in Cambodia using the atraumatic restorative treatment (ART) technique and Fuji II glass ionomer cement. Int J Paediat Dent 8:35-40

47. Abid A, Chkir F, Ben Salem K, Argoubi K, Sfar-Gandoura M (2002) Atraumatic restorative treatment and glass ionomer sealants in Tunesian children: survival after 3 years. East Med Health J 8:315-23

48. Motsei SM, Kroon J, Holtshousen WS (2001) Implementation of the ART approach in South Africa: an activity report. S Afr Dent J $56: 327-329$

49. Kalf-Scholte SM, Van Amerongen WE, Smith AJE, Van Haastrecht HJA (2003) Atraumatic restorative treatment (ART): a three-year clinical study in Malawi - comparison of conventional amalgam and ART restorations. J Public Health Dent 63:99-103

50. Phantumvanit P, Songpaisan Y, Pilot T, Frencken JE (1996) Atraumatic restorative treatment (ART). Survival of one-surface restorations in the permanent dentition. J Public Health Dent $56: 141-145$

51. Mandari GJ, Truin GJ, Van'T Hof MA, Frencken JE (2001) Effectiveness of three minimal intervention approaches for managing dental caries: survival of restorations after 2 years. Caries Res 35:90-94

52. Mandari GJ, Frencken JE, Van'T Hof MA (2003) Six-year success rates of occlusal amalgam and glass-ionomer restorations placed using three minimal intervention approaches. Caries Res 37:246-253

53. Frencken JE, Makoni F, Sithole WD, Hackenitz E (1998) Threeyear survival of one-surface ART restorations and glass-ionomer sealants in a school oral health programme in Zimbabwe. Caries Res 32:119-126

54. De Souza EM, Cefaly DF, Terada RS, Rodrigues CC, De Lima Navarro MF (2003) Clinical evaluation of the ART technique using high density and resin-modified glass ionomer cements. Oral Health Prev Dent 1:201-207

55. Frencken JE, Songpaisan Y, Phantumvanit P, Pilot T (1994) Atraumatic restorative treatment (ART) technique: evaluation after 1 year. Int Dent J 44:460-464

56. Wang L, Lopes LG, Bresciani E, Lauris JR, Mondelli RF, De Lima Navarro MF (2004) Evaluation of class I ART restorations in Brazilian schoolchildren; three-year results. Spec Care Dent 24:28-33

57. Lo ECM, Holmgren CJ (2001) Provision of atraumatic restorative treatment (ART) restorations to Chinese pre-school children-a 30 month evaluation. Int J Paediat Dent 11:3-10 
58. Yee R (2001) An ART field study in western Nepal. Int Dent J 51:103-108

59. van Den Dungen GM, Huddleston Slater AE, van Amerongen WE (2004) ART of conventioneel? Onderzoeksresultaten van proximale restauraties in tijdelijke molaren. Ned Tijdschr Tandheelk 111:345349

60. Zanata RL, Navarro MFL, Barbosa SH, Lauris JRP, Franco EB (2003) Clinical evaluation of three restorative materials applied in a minimal intervention caries treatment approach. J Public Health Dent 63:221-226

61. Falbo S, Grisoski M, Vivone G, Zac L (2002) Dos años de atención comunitária con tecnica atraumática en ninõs escolares. Rev Asoc Odontol Argent 90:171-174

62. Moraes NM, Knupp R, Cabral I (2004) Avaliação de dezoito meses de um programa de saúde bucal em alunos de uma escola municipal do Rio de Janeiro. Rev Bras Odontol 61:227-228

63. Oliveira MT, Bittencourt ST, Oliveira MDS, Roberta H, Pereira JR (2009) Avaliação clínica do desempenho de TRA (tratamento restaurador atraumático) associado a um agente químico de remoção de cárie. Rev Odontol Ciênc 24:190-193

64. Silva JJS, Carvalho RB, Batittucci MHG, Silva KRS (2005) Tratamento restaurador atraumático (TRA) em escolares do Morro São Benedito, município de Vitória, ES. J Bras Clín Odontol Integr 9:24-30

65. Bresciani E, Nogueira DA, Henostroza Quintans N, Barata TJE, Lauris JRP, Navarro MFL (2002) Influência do isolamento absoluto sobre o sucesso do tratamento restaurador atraumático (ART) em cavidades classe II, em dentes decíduos. Rev Fac Odontol Bauru 10:231-237

66. Peres SHCS, Hussne R, Peres AS (2005) Tratamento restaurador atraumático (ART) em crianças de 4 a 7 anos: avaliação clínica após 6 meses. Rev Inst Ciênc Saúde 23:275-280

67. Coelho FSM, Ribeiro CCC (2002) Restaurações atraumáticas em odontopediatria (ART). Rev Gaú Odontol 50:105-110

68. Ewoldsen N, Cacho Z, Callahan S, Froeschle ML, Goel Brackett M (1999) Tratamiento restaurador no traumático usando uma mezcla de cementos de ionómero de vidrio. Rev Asoc Dent Mex 56:8-11

69. Oliveira LMC (2000) Avaliação de um programa de tratamento restaurador atraumático em crianças institucionalizadas. $\mathrm{PhD}$ Thesis, Rio de Janeiro, p 168

70. Bustamante C, Edelberg MH (2004) Tratamiento restaurador atraumático (TRA) em dientes permanentes jóvenes. Resultados de 3 años: un procedimiento válido para la prevención e inactivación de caries en el marco de un programa comunitario de atención primaria. Rev Asoc Odontol Argent 92:155-159

71. Edelberg MH, Basso ML (2000) Tratamiento restaurador atraumático. Rev Asoc Odontol Argent 88:43-47

72. Figueiredo MC, Froner AM, Rosito DB, Gallarreta FWM, Sampaio MS (1999) A utilização da técnica de Tratamento Restaurador Atraumático (ART) em bebês: avaliação clínica de um ano. J Bras Odontopediatr Odontol Bebê 2:362-368

73. Honkala E, Behbehani J, Ibricevic H, Kerosuo E, Al-Jame G (2003) The atraumatic restorative treatment (ART) approach to restoring primary teeth in a standard dental clinic. Int J Paediat Dent 13:172-179

74. Taifour D, Frencken JE, Beiruti N, Hof MA, Truin GJ (2002) Effectiveness of glass-ionomer (ART) and amalgam restorations in the deciduous dentition-results after 3 years. Caries Res $36: 437-444$

75. Yip HK, Smales RJ, Yu C, Deng DM (2002) Comparison of atraumatic restorative treatment and conventional cavity prepara- tions for glass-ionomer restorations in primary molars: 1-year results. Quintessence Int 33:17-21

76. Yu C, Gao X-J, Deng D-M, Yip H-K, Smales RJ (2004) Survival of glass ionomer restorations placed in primary molars using atraumatic restorative treatment (ART) and conventional cavity preparations: 2-year results. Int Dent J 54:42-46

77. Louw AJ, Sarvan I, Chikte UME, Honkala E (2002) One-year evaluation of atraumatic restorative treatment and minimal intervention techniques on primary teeth. S Afr Dent J 57:366371

78. Luo Y, Wei SHY, Fan MW, Lo ECM (1999) Clinical investigation of a high-strength glass ionomer restorative used with the ART technique in Wuhan, China: 1-year results. Chin J Dent Res 2:7378

79. Lo ECM, Luo Y, Fan MW, Wei SHY (2001) Clinical investigation of two glass-ionomer restoratives used with the atraumatic restorative treatment approach in China: 2-years results. Caries Res 35:458-463

80. Ersin NK, Candan U, Aykut A, Onçag O, Eronat C, Kose T (2006) A clinical evaluation of resin-based composite and glass ionomer cement restorations placed in primary teeth using the ART approach: results at 24 months. J Am Dent Assoc 137:15291536

81. Yassen G (2009) One-year survival of ART occlusal restorations in primary molars placed with and without cavity conditioner ASDC J Dent Child 76:136-141

82. Ziraps A, Honkala E (2002) Clinical trial of a new glass ionomer for an atraumatic restorative treatment technique in class I restorations placed in Latvian school children. Med Princ Pract 11:44-47

83. Lo EC, Holmgren CJ, Hu D, van Palenstein HW (2007) Six-year follow up of atraumatic restorative treatment restorations placed in Chinese school children. Community Dent Oral Epidemiol 35:387-392

84. Ho TFT, Smales RJ, Fang DKS (1999) A 2-year clinical study of two glass ionomer cements used in the atraumatic restorative treatment (ART) technique. Community Dent Oral Epidemiol 27:195-201

85. Kikwilu EN, Mandari GJ, Honkala E (2001) Survival of Fuji IX fillings in permanent teeth of primary school children in Tanzania. East Afr Med J 78:19-21

86. Frencken JE, Taifour D, Van't Hof MA (2006) Survival of ART and amalgam restorations in permanent teeth of children after 6.3 years. J Dent Res 85:622-626

87. Yip KH-K, Smales RJ, Gao W, Peng D (2002) The effects of two cavity preparation methods on longevity of glass ionomer cement restorations. An evaluation after 12 months. J Am Dent Assoc 133:744-751

88. Gao W, Peng D, Smales R, Yip KHK (2003) Comparison of atraumatic restorative treatment and conventional restorative procedures in a hospital clinic: Evaluation after 30 months. Quintessence Int 34:31-37

89. Mickenautsch S, Rudolph MJ, Ogunbodede EO, Frencken JE (1999) The impact of the ART approach on the treatment profile in a mobile dental system (MDS) in South Africa. Int Dent J 49:132-138

90. Vieira ALF, Zanella NLM, Bresciani E, Barata TJE, Silva SMB, Machado MAAM, Navarro MFL (2006) Evaluation of glass ionomer sealants placed according to the ART approach in a community with high-caries experience: 1-year follow-up. J Appl Oral Sci 14:270-275 